\title{
Pengaruh Current Ratio, Debt to Asset Ratio, Firm Size dan Perputaran Modal Kerja terhadap Profitabilitas (ROA) pada Perusahaan Wholesale dan Retail Trade yang Terdaftar Di Bursa Efek Indonesia Pada Periode 2013-2017
}

\author{
NopitaSari \\ Universitas Prima Indonesia \\ Vie.nov95@gmail.com
}

\author{
Ronald Hasudungan \\ Rajagukguk
}

Universitas Prima Indonesia

Ronald.hasudungan72@

yahoo.com

Ivana

Universitas Prima Indonesia ivanakesuma@yahoo.com
Selin Govinna

Universitas Prima Indonesia

selin.govinna@gmail.com

\author{
Mas Intan Purba \\ Universitas Prima Indonesia \\ Masintanpurba84@gmail.com
}

\section{Abstract}

This study aims to determine whether there is a partial influence Current Ratio, Debt To Asset Ratio, Firm Size and Working Capital Turnover Against Profitability (ROA). This study uses quantitative research. The population in this study were all Wholesale andRetail trade companies listed on the Indonesia Stock Exchange (IDX) and continuously published financial reports in 2013-2017. Based on the purposive sampling method, the samples obtained were 20 companies for each year in the period 2013-2017, so that the data obtained were 100 observation data. The analytical method used is multiple regression analysis. The results of the study state that partially the Current Ratio, Debt to Asset Ratio, Firm size and working capital turnover have an effect on profitability (ROA).

Keywords :Current Ratio,Debt to Asset Ratio, Firm size, dan Working Capital Turnover, Profitability (ROA).

\section{PENDAHULUAN}

Perusahaan di Indonesia terdiri dari beberapa jenis sektor industri, salah satunya sektor Wholesale dan Retail Trade. Profitabilitas dapat menggunakan rasio Return On Asset. Seiring dengan meningkatnya gaya hidup dan daya beli masyarakat, setiap tahun perusahaan ini semakin berkembang. Dimulai pada tahun
1989 dengan PT. United Tractor dan PT. Matahari Departement Store TBK sebagai perusahaan Wholesale dan Retail Trade tercatat pertama, Sektor ini terus berkembang sampai dengan 2017 tercatat sudah ada 37 perusahaan Wholesale dan 25 perusahaan Retail Trade yang terdaftar di Bursa Efek. Aset lancar merupakan aset yang paling cepat dapat dipergunakan 
untuk memenuhi kewajiban hutang jangka penjang dan jangka pendek perusahaan.

Hutang yang dimiliki perusahaan dapat menimbulkan beban bunga bagi perusahaan. Akan tetapi, apabila hutang tersebut di manfaatkan dengan baik, maka kinerja dan keuntungan perusahaan akan meningkat.

Modal kerja merupakan penunjang kegiatan operasional perusahaan. Modal kerja ini memiliki dana yang tidak produktif di perusahaan, sehingga akan rugi bagi perusahaan.

Tabel 1.2

Data Aset Lancar, Total Hutang, Total Aset, Penjualan, dan Laba Pada Perusahaan Wholesale dan Retail Trade Yang Terdaftar di Bursa Efek Indonesia Pada Periode 2013-2017 (Dalam Jutaan Rupiah)

\begin{tabular}{|c|c|c|c|c|r|r|}
\hline \multirow{2}{*}{ Perusahaan } & Tahun & $\begin{array}{c}\text { Aset } \\
\text { Lancar }\end{array}$ & $\begin{array}{c}\text { Total } \\
\text { Hutang }\end{array}$ & $\begin{array}{c}\text { Total } \\
\text { Aset }\end{array}$ & Penjualan & \multicolumn{1}{c|}{ Laba } \\
\hline \multirow{4}{*}{$\begin{array}{c}\text { PT Ace Hardware } \\
\text { Indonesia Tbk }\end{array}$} & 2013 & 1.747 .185 & 563.420 & 2.478 .919 & 3.895 .446 & 503.004 \\
\cline { 2 - 7 } & 2014 & 2.171 .085 & 585.200 & 2.947 .349 & 4.541 .474 & 548.893 \\
\cline { 2 - 7 } & 2015 & 2.467 .395 & 638.724 & 3.267 .550 & 4.742 .526 & 584.873 \\
\cline { 2 - 7 } & 2016 & 2.822 .070 & 682.374 & 3.731 .102 & 4.935 .903 & 706.150 \\
\cline { 2 - 7 } & 2017 & 3.358 .272 & 918.419 & 4.428 .841 & 5.938 .576 & 780.687 \\
\hline \multirow{4}{*}{$\begin{array}{c}\text { PT Enseval Putera } \\
\text { Megatrading Tbk }\end{array}$} & 2013 & 4.563 .090 & 2.489 .216 & 5.528 .068 & 15.623 .240 & 464.372 \\
\cline { 2 - 7 } & 2014 & 5.116 .991 & 2.640 .735 & 6.190 .618 & 17.011 .550 & 510.664 \\
\cline { 2 - 7 } & 2016 & 5.621 .266 & 2.677 .691 & 6.747 .937 & 17.476 .103 & 547.174 \\
\cline { 2 - 7 } & 2017 & 6.119 .206 & 2.295 .031 & 7.425 .800 & 19.669 .097 & 517.836 \\
\hline \multirow{4}{*}{ PT Catur Sentosa } & 2013 & 2.265 .881 & 2.391 .021 & 3.107 .895 & 6.321 .157 & 75.880 \\
\cline { 2 - 7 } Adiprana Tbk & 2014 & 2.541 .776 & 2.490 .040 & 3.308 .918 & 6.997 .923 & 114.689 \\
\cline { 2 - 7 } & 2015 & 2.554 .325 & 2.669 .054 & 3.522 .573 & 7.117 .833 & 43.022 \\
\cline { 2 - 7 } & 2016 & 3.134 .577 & 2.829 .046 & 4.240 .820 & 7.764 .889 & 74.637 \\
\cline { 2 - 7 } & 2017 & 3.662 .500 & 3.612 .982 & 5.138 .259 & 9.342 .144 & 89.022 \\
\hline \multirow{4}{*}{$\begin{array}{c}\text { PT Erajaya } \\
\text { Swasembada Tbk }\end{array}$} & 2013 & 3.777 .773 & 2.248 .291 & 5.001 .635 & 12.727 .248 & 348.615 \\
\cline { 2 - 7 } & 2014 & 4.318 .605 & 3.106 .521 & 6.120 .307 & 14.451 .413 & 214.387 \\
\cline { 2 - 7 } & 2015 & 5.465 .564 & 4.594 .894 & 7.800 .300 & 20.007 .598 & 229.812 \\
\cline { 2 - 7 } & 2016 & 5.168 .223 & 4.015 .443 & 7.424 .604 & 20.547 .128 & 261.721 \\
\hline
\end{tabular}

Sumber : data diolah peneliti (2018)

Berdasarkan tabel I.1,PT Ace Hardware Indonesia Tbk pada tahun 20132014, aset lancar perusahaan meningkat sebesar Rp 423.900 (24,26\%), akan tetapi keuntungan yang dihasilkan perusahaan akan meningkat sebesar Rp 45.889 $(9,12 \%)$.

PT Enseval Putera Megatrading Tbk pada tahun 2015-2016, hutang yang dimiliki perusahaan menurun sebesar $\mathrm{Rp}$ 210.402 (7,86\%), akan tetapi keuntungan yang dihasilkan perusahaan akan meningkat sebesar Rp 8.947 (1.64\%).

PT Catur Sentosa Adiprana Tbk, pada tahun 2014-2015 total aset perusahaan meningkat sebesar Rp 213.655 perusahaan menurun sebesar Rp 71.667 (62,49\%).

PT Erajaya Swasembada Tbk, pada tahun 2014-2015 penjualan perusahaan 
meningkat sebesar Rp 5.556.185 (38,45\%) akan tetapi keuntunganyang dihasilkan perusahaan akan meningkat sebesar Rp $15.425(7,19 \%)$.

\section{TINJAUAN PUSTAKA}

Berbicara mengenai wholesale dan retail trade, maka tidak akan lepas dari penjualan. Wholesale itu menjual produk dalam jumlah besar, produk tersebut akan di jual kembali kepada konsumen sedangkan Retail trade menjual produk secara langsung kepada konsumen lazim atau disebut pengecer.

\section{A. Current Ratio}

Menurut Munawir (2016:72), Current ratio adalah menyatakan bahwa nilai kekayaan lancar (yang segera dapat di jadikan uang) ada sekian kalinya hutang jangka pendek.

Menurut Hery (2016:152), rasio lancar adalah rasio untuk mengukur kemampuan perusahaan dalam membayar hutangjangka pendeknya yang sudah lewat periode.

\section{B.Debt To Asset Ratio}

Menurut hery (2016:166) Debt to Asset Ratio digunakan untuk menghitung kesetaraan antara total utang dengan total aset.

Menurut Silaban (2011:100), debt ratio adalah rasio yang memperlihatkan proporsi antara kewajiban yang dimiliki perusahaan dengan seluruh kekayaan yang dimiliki perusahaan.

\section{C.Firm size}

Menurut Pangestuti (2016:4) ukuran perusahaan adalah suatu skala yang menentukan besar kecilnya perusahaan yang dapat dilihat dari nilai equity.

Menurut meidiyustiani (2016:164) ukuran perusahaan merupakan suatu penetapan besar kecilnya perusahaan.

\section{Perputaran modal kerja}

Menurut sawir (2010:16) perputaran modal kerja dapat diperoleh dari banyaknya penjualan perusahaan.

Menurut Munawir (2016:80) menyatakan bahwa rasio perputaran modal kerja menunjukkan hubungan antara modal kerja dengan penjualan

\section{E. Profitabilitas}

Menurut silaban (2011:106) profitabilitas adalahkinerja perusahaan dalam menghasilkan laba.

Menurut Hery (2016:163) rasio profitabilitas digunakan untuk mengukur kinerja perusahaan untuk menghasilkan keuntungan dari aktivitas normal bisnisnya.

\section{Metode Penelitian}

\section{Tempat dan Waktu Penelitian}

Penelitian ini menggunakan perusahaan Wholesale dan Retail Trade yang terdaftar di Bursa Efek Indonesia periode 2013-2017 melalui media internet lewat situs resmi BEI, yaitu www.idx.com.id . waktu penelitian direncanakan selama 6 bulan terhitung april 2019 - september 2019.

\section{A.Current Ratio}

$$
\text { Current ratio }=\frac{\text { Current assets }}{\text { Current liabilities }}
$$

Current Ratio adalah pada umum yang digunakan untuk mengetahui kemampuanperusahaan untuk membayar hutang jangka pendek. Rumus yang digunakan untuk adalah

\section{B. Debt to Asset Ratio}

Rasio hutang terhadap aset digunakan untuk mengukur kesetaraan antara total hutang dengan total aset. Rumus yang digunakan adalah 
Debt to asset ratio $=\frac{\text { Totaldebt }}{\text { Total asset }}$

\section{C.Firm size}

Firm size merupakan nilai kekayaan total perusahaan. Rumus yang digunakan adalah

Firm size $=$ Ln (total aktiva)

\section{D.Perputaran Modal Kerja}

Perputaran Modal Kerjamerupakan rasio untuk mengukur atau menilai keefektifan modal kerja perusahaan selama periode tertentu .Untuk mengukur rasio ini kita membandingkan antara penjualan dengan modal kerja .

Rumus yang digunakan adalah

$$
\text { Perputaran modal kerja }=\frac{\text { Sales }}{\text { Net working capital }}
$$

\section{E. Return On Asset}

$$
\text { Return on asset }=\frac{\text { Net income }}{\text { Total Assets }}
$$

Profitabilitas merupakan kinerja perusahaan dalam menghasilkan laba. Rumus yang digunakan adalah

\section{F. Kerangka konseptual dan}

Pengembangan hipotesis

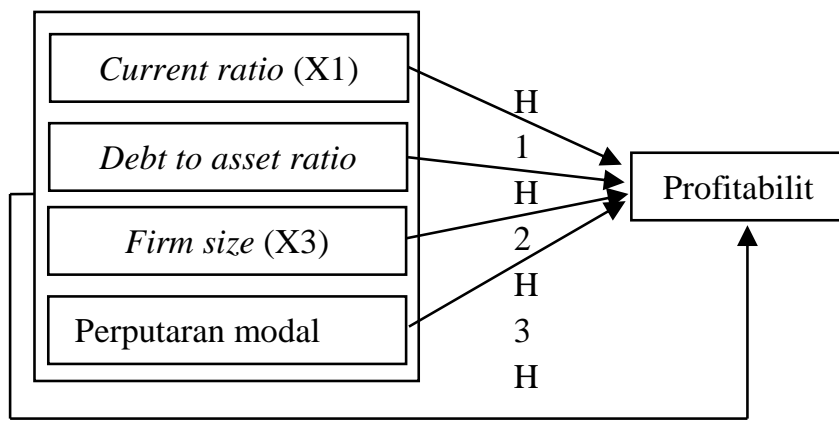

\section{Gambar1 Kerangka septual}

Berdasarkan kerangka konseptual di atas, maka hipotesis dalam penelitian ini adalah :

$\mathrm{H}_{1}$ : $\quad$ Current Ratio berpengaruh secara parsial terhadap profitabilitas pada perusahaan Wholesale dan Retail Trade yang terdaftar di Bursa Efek Indonesia pada periode 2013-2017.

$\mathrm{H}_{2}$ : Debt to Asset Ratio berpengaruh secara parsial terhadap profitabilitas pada perusahaan Wholesale dan Retail Trade yang terdaftar di Bursa Efek Indonesia pada periode 20132017.

H3 : Firm Size berpengaruh secara parsial terhadap profitabilitas pada perusahaan Wholesale dan Retail Trade yang terdaftar di Bursa Efek Indonesia pada periode 2013-2017.

$\mathrm{H}_{4}$ : Perputaran modal kerja berpengaruh secara parsial terhadap profitabilitas pada perusahaan Wholesale dan Retail Trade yang terdaftar di Bursa Efek Indonesia pada periode 2013-2017.

$\mathrm{H}_{5}$ : Current ratio, debt to asset ratio, firm size, dan perputaran modal kerja berpengaruh secara simultan terhadap profitabilitas pada perusahaan Wholesale dan Retail Trade yang terdaftar di Bursa Efek Indonesia pada periode 2013-2017.

\section{METODE PENELITIAN Tempat dan Waktu Penelitian}

Penelitian dilaksanakan pada perusahaan Wholesale dan Retail Trade yang terdaftar di Bursa Efek Indonesia periode 2013-2017 melalui media internet lewat situs resmi BEI, yaitu www.idx.co.id. Waktu penelitian direncanakan selama 6 bulan terhitung April 2019 sampai dengan bulan September 2019. 


\section{Pendekatan Penelitian}

Pendekatan penelitian ini menggunakan metode penelitian kuantitatif. Menurut Sugiyono (2016:7), penelitian kuantitatif digunakan untuk meneliti pada populasi atau sampel tertentu, pengumpulan data menggunakan analisis data yang bersifat statistik.

\section{Jenis Penelitian}

Jenis penelitian yang digunakan adalah penelitian deskriptif kuantitatif. Menurut Sugiyono (2016:8), deskriptif kuantitatif adalah metode yang berfungsi untuk mendeskripsikan atau memberi gagasan terhadap objek yang diteliti dan telah ditetapkan.

\section{Sifat Penelitian}

Penelitian ini bersifat explanatory. Menurut Zulganef (2013:11), penelitian explanatory adalah penelitian yang bertujuan menelaah kausalitas antar variabel yang menjelaskan suatu fenomena tertentu.

\section{Populasi}

Menurut Sugiyono (2016:80), populasi bukan hanya orang, tetapi juga objekdan benda-benda alam yang lain. Populasi bukan sekedar jumlah yang ada pada objek atau subjek yang dipelajari, tetapi meliputi seluruh karakteristik/sifat yang dimiliki oleh subjek atau objek itu. Populasi dalam penelitian ini menggunakan seluruh perusahaan Wholesale dan Retail Trade yang terdaftar di Bursa Efek Indonesia dari tahun 2013-2017, sebanyak 62 perusahaan.

\section{Sampel}

Menurut Sugiyono (2016:81), sampel adalah bagian yang dimiliki oleh populasi. Teknik pengambilan sampel menggunakan teknik purposive sampling, yaitu populasi yang dijadikan sampel penelitian adalah yang memenuhi kriteria kriteria sampel tertentu sesuai dengan yang diinginkan peneliti dan dipilih berdasarkan pertimbangan tertentu disesuaikandengan tujuan penelitian yang akan dicapai.

\section{HASIL DAN PEMBAHASAN Tabel IV.3}

\begin{tabular}{|l|r|r|r|r|r|}
\hline & $\mathrm{N}$ & $\begin{array}{c}\text { Minimu } \\
\mathrm{m}\end{array}$ & Maximum & \multicolumn{1}{c|}{ Mean } & $\begin{array}{c}\text { Std. } \\
\text { Deviation }\end{array}$ \\
\hline & 100 & 1.0735 & 42.3301 & 2.771451 & 4.4889875 \\
\hline CR & 100 & .1829 & .8254 & .492258 & .1784638 \\
\hline DAR & 100 & 19.1200 & 32.0409 & 27.944373 & 3.2380191 \\
\hline Firm Size & 100 & 1.3216 & 44.8502 & 9.634111 & 9.6697879 \\
\hline WCTO & 100 & .0032 & .2029 & .062790 & .0381487 \\
\hline ROA & 100 & & & & \\
\hline $\begin{array}{l}\text { Valid N } \\
\text { (listwise) }\end{array}$ & & & & & \\
\hline
\end{tabular}

\section{Statistik Deskriptif}

Sumber : Hasil Output SPSS (2019)

Berdasarkan tabel IV.3, menunjukkan nilai tertinggi, terendah dan rata-rata, standar deviasi dari variabel Current Ratio (CR),Debt To Asset Ratio (DAR), Firm Size, perputaran modal kerja (WCTO), dan profitabilitas (ROA) dengan 100 observasi selama tahun 2013-2017.

\section{Variabel Current Ratio (X1)} memiliki nilai minimum sebesar 1,0735pada PT Catur Sentosa Adiprana Tbk, nilai maksimum sebesar 42,3301pada PT Inter Delta Tbk, nilai rata-rata sebesar 2,771451, dan standar deviasi sebesar 4,4889875 .

Variabel Debt to Asset Ratio $\left(\mathrm{X}_{2}\right)$ memiliki nilai minimum sebesar 0,1829 pada PT Ace Hardware IndonesiaTbk, nilai maksimum sebesar 0,8254 pada PT FKS Multi AgroTbk, nilai rata-rata sebesar 0,492258, dan standar deviasi sebesar 3,2380191 .

Variabel Firm Size (X3) memiliki nilai minimum sebesar 19,1200pada PT FKS Multi AgroTbk, nilai maksimum sebesar 32,0409pada PT United TractorsTbk, nilai rata-rata sebesar 
27,944373, dan standar deviasi sebesar 0,0857490 .

Variabel Perputaran Modal Kerja $\left(\mathrm{X}_{4}\right)$ memiliki nilai minimum sebesar 1,3216pada PT Inter DeltaTbk, nilai maksimum sebesar 44,8502pada PT FKS Multi AgroTbk, nilai rata-rata sebesar 9,634111, dan standar deviasi sebesar 9,6697879 .

Variabel profitabilitas (Y) memiliki nilai minimum sebesar 0,0032pada PT Mitra AdiperkasaTbk, nilai maksimum sebesar 0,2029pada PT Ace Hardware IndonesiaTbk, nilai rata-rata sebesar 0,062790, dan standar deviasi sebesar 0,0381487 .

\section{A.Uji asumsi klasik}

\section{Uji Normalitas}

Tujuan uji normalitas adalah untuk menguji apakah data residual sudah berdistribusi secara normal atau tidak. Penelitian ini menggunakan analisis histogram, normal probability plot, dan Kolmogorov-Smirnov. Berikut tampilan hasil pengujian :

Berikut adalah hasil dari uji statistik Kolmogorov-Smirnov Test :

Tabel 5.5 : Uji Normalitas Kormogorov Smirnov

\begin{tabular}{|l|l|r|}
\hline \multicolumn{2}{|c|}{ One-Sample Kolmogorov-Smirnov Test } \\
\hline \multicolumn{2}{|c|}{} & $\begin{array}{c}\text { Unstandardized } \\
\text { Residual }\end{array}$ \\
\hline $\mathrm{N}$ & Mean & .0000000 \\
\cline { 2 - 3 } $\begin{array}{l}\text { Normal } \\
\text { Parameters }{ }^{\mathrm{a}, \mathrm{b}}\end{array}$ & Std. Deviation & .02124785 \\
\hline \multirow{2}{*}{$\begin{array}{l}\text { Most Extreme } \\
\text { Differences }\end{array}$} & Absolute & .055 \\
\cline { 2 - 3 } & Positive & .044 \\
\cline { 2 - 3 } & Negative & -.055 \\
\hline Kolmogorov-Smirnov Z & .517 \\
\hline Asymp. Sig. (2-tailed) & .952 \\
\hline a. Test distribution is Normal. \\
\hline b. Calculated from data. \\
\hline
\end{tabular}

Sumber : Hasil output SPSS (2019)
Berdasarkan tabel IV.5, dapat dilihat bahwa variabel residual memiliki tingkat signifikansi 0,952. Hal ini menunjukkan tingkat signifikansi lebih besar 0,05 $(0,952>0,05)$, maka dapat ditarik kesimpulan bahwa databerdistribusi normal.

\section{Uji Multikolinearitas}

multikolinearitas di antara variabel independen.

Tabel 4.6 : Uji Multikolinearitas

\begin{tabular}{|c|c|c|c|c|c|c|c|c|}
\hline \multicolumn{9}{|c|}{ Coefficients $^{a}$} \\
\hline & \multirow{2}{*}{ Model } & \multicolumn{2}{|c|}{$\begin{array}{l}\text { Unstandardized } \\
\text { Coefficients }\end{array}$} & \multirow{2}{*}{$\begin{array}{c}\begin{array}{c}\text { Standardi } \\
\text { zed } \\
\text { Coefficie } \\
\text { nts }\end{array} \\
\text { Beta }\end{array}$} & \multirow{2}{*}{$\mathrm{t}$} & \multirow{2}{*}{ Sig. } & \multicolumn{2}{|c|}{$\begin{array}{l}\text { Collinearity } \\
\text { Statistics }\end{array}$} \\
\hline & & B & $\begin{array}{l}\text { Std. } \\
\text { Error }\end{array}$ & & & & $\begin{array}{c}\text { Tolera } \\
\text { nce }\end{array}$ & VIF \\
\hline \multirow{5}{*}{1} & (Constant) & .102 & .025 & & 4.035 & .000 & & \\
\hline & $\mathrm{CR}$ & -.002 & .002 & -.078 & -.717 & .475 & .700 & 1.429 \\
\hline & DAR & -.103 & .018 & -.661 & -5.552 & .000 & .580 & 1.725 \\
\hline & Firm Size & .000 & .001 & .031 & .335 & .739 & .944 & 1.059 \\
\hline & WCTO & .000 & .000 & .132 & 1.091 & .278 & .560 & 1.786 \\
\hline
\end{tabular}

Sumber : Hasil output SPSS (2019)

Berdasarkan tabel IV.6, dapat dilihat bahwa Current Ratio (CR) memiliki nilai tolerance 0,700 dan nilai VIF 1,429 , Debt to Asset Ratio (DAR) memiliki nilai tolerance 0,580 dan nilai VIF 1725, Firm Sizememiliki nilai tolerance 0,944 dan nilai VIF 1,059, dan perputaran modal kerja (WCTO) memiliki nilai tolerance 0,560 dan nilai VIF 1,786. Semua variabel memiliki nilai VIF kurang dari 10 dan nilai tolerance> 0,10.Maka dapat ditarik kesimpulan bahwa tidak terdapat

\section{Uji Autokorelasi}

Tabel 4.7:Uji Autokorelasi

\begin{tabular}{|l|r|}
\hline \multicolumn{2}{|c|}{ Runs Test } \\
\hline & $\begin{array}{c}\text { Unstandardized } \\
\text { Residual }\end{array}$ \\
\hline Test Value & .00191 \\
\hline Cases < Test Value & 44 \\
\hline Cases >= Test Value & 44 \\
\hline Total Cases & 88 \\
\hline
\end{tabular}




\begin{tabular}{|l|r|}
\hline Number of Runs & 42 \\
\hline$Z$ & -.643 \\
\hline Asymp. Sig. (2-tailed) & .520 \\
\hline a. Median \\
\hline \multicolumn{2}{|c|}{ Sumber : Hasil output SPSS (2019) }
\end{tabular}

Berdasarkan tabel IV.7, dapat dilihat bahwa variabel residual memiliki tingkat signifikansi 0,520 . Hal ini menunjukkan tingkat signifikansi lebih besar $0,05 \quad(0,520>0,05)$, maka ditarik kesimpulan bahwa tidak terjadi autokorelasi.

\section{Uji Heteroskedastisitas}

\section{Tabel 4.8 :Uji Heteroskedastisitas dengan Glejser}

\begin{tabular}{|c|c|c|c|c|c|c|}
\hline \multicolumn{7}{|c|}{ Coefficients $^{\mathrm{a}}$} \\
\hline & \multirow[t]{2}{*}{ Model } & \multicolumn{2}{|c|}{$\begin{array}{l}\text { Unstandardized } \\
\text { Coefficients }\end{array}$} & \multirow{2}{*}{$\begin{array}{c}\begin{array}{l}\text { Standardized } \\
\text { Coefficients }\end{array} \\
\text { Beta }\end{array}$} & \multirow[t]{2}{*}{$\mathrm{t}$} & \multirow[t]{2}{*}{ Sig. } \\
\hline & & $\mathrm{B}$ & Std. Error & & & \\
\hline \multirow{5}{*}{1} & (Constant) & .027 & .014 & & 1.916 & .059 \\
\hline & CR & -.001 & .001 & -.078 & -.597 & .552 \\
\hline & DAR & .007 & .010 & .099 & .694 & .489 \\
\hline & Firm Size & .000 & .000 & -.092 & -.822 & .413 \\
\hline & WCTO & .000 & .000 & -.143 & -.988 & .326 \\
\hline
\end{tabular}

a. Dependent Variable: abs_res

Sumber : Hasil output SPSS (2019)

Berdasarkan tabel IV.8, dapat dilihat bahwaCurrent Ratio (CR) memiliki signifikansi 0,552, Debt to Asset Ratio (DAR) memiliki signifikansi 0,489, Firm size memiliki signifikansi 0,413, dan perputaran modal kerja (WCTO) memiliki signifikansi 0,326. Semua variabel memiliki nilai signifikansi > 0,05. Maka dapat ditarik kesimpulkan bahwa tidak terjadi heteroskedastisitas.

\section{B. Uji Hipotesis}

1.Koefisien determinasi hipotesis.

Tabel 4.10 : Uji Koefisien Determinasi

\begin{tabular}{|l|c|c|c|c|}
\hline \multicolumn{5}{|c|}{ Model Summary } \\
\hline Model & $\mathrm{R}$ & R Square & $\begin{array}{c}\text { Adjusted R } \\
\text { Square }\end{array}$ & $\begin{array}{c}\text { Std. Error of } \\
\text { the Estimate }\end{array}$ \\
\hline 1 & $.565^{\mathrm{a}}$ & .319 & .286 & .0217538 \\
\hline a. Predictors: (Constant), WCTO, Firm Size, CR, DAR \\
\hline
\end{tabular}

Sumber : Hasil output SPSS (2019)
Berdasarkan tabel IV.10, dapat dilihat nilai Adjusted $R$ Squaresebesar 0,286 atau sama dengan $28,6 \%$. Ini artinya kemampuan variable current ratio, debt to asset ratio, firm size, dan perputaran modal kerja secara bersama-sama dalam menjelaskan profitabilitas adalah sebesar $28,6 \%$, sedangkan sisanya $71,4 \%$ dipengaruhi faktor-faktor lain yang tidak ada didalam penelitian ini, seperti debt to equity ratio,total asset turnover, dan lain sebagainya.

2.Pengujian hipotesis secara simultan (uji f)

Tabel 4.11: Uji F

\begin{tabular}{|c|c|c|c|c|c|c|}
\hline \multicolumn{7}{|c|}{ ANOVA $^{\mathrm{a}}$} \\
\hline \multicolumn{2}{|c|}{ Model } & Sum of & df & Mean & $\mathrm{F}$ & Sig. \\
\hline \multirow{3}{*}{1} & Regression & .018 & 4 & .005 & 9.711 & $.000^{\mathrm{b}}$ \\
\hline & Residual & .039 & 83 & .000 & & \\
\hline & Total & .058 & 87 & & & \\
\hline \multicolumn{7}{|c|}{ a. Dependent Variable: ROA } \\
\hline \multicolumn{7}{|c|}{ b. Predictors: (Constant), WCTO, Firm Size, CR, DAR } \\
\hline
\end{tabular}

Berdasarkan hasil uji $F$ yang terdapat pada tabel IV.11, dapat dilihat nilai Fhitung $(9,711)$ dengansignifikansi 0,000 sedangkan $\mathrm{F}_{\text {tabel }}(2,47$, dimana $\mathrm{N} 2=\mathrm{n}-\mathrm{k}=95$, $\mathrm{N} 1=\mathrm{k}-1=4)$ dengan signifikansi 0,05. Dengan demikian dapat dilihat bahwa $F_{\text {hitung }}$ lebih besar dari $F_{\text {tabel }}$ dan signifikansi tidaklebihbesar0,05 sehingga hipotesis diterima, dimana current ratio, debt to asset ratio, firm size, dan perputaran modal kerja secara simultan berpengaruh signifikan terhadap profitabilitas pada perusahaan Wholesale dan Retail Trade yang terdaftar di Bursa Efek Indonesia pada periode 20132017.

3.Pengujian hipotesis secara parsial ( uji t)

Tabel 4.12 : Uji t

\begin{tabular}{|c|c|c|c|c|c|c|}
\hline \multicolumn{7}{|c|}{ Coefficients $^{a}$} \\
\hline & \multirow[t]{2}{*}{ Model } & $\begin{array}{r}\text { Unstal } \\
\text { Coef }\end{array}$ & $\begin{array}{l}\text { dardized } \\
\text { icients }\end{array}$ & $\begin{array}{l}\text { Standardized } \\
\text { Coefficients }\end{array}$ & \multirow[t]{2}{*}{$\mathrm{t}$} & \multirow[t]{2}{*}{ Sig. } \\
\hline & & $\mathrm{B}$ & Std. Error & Beta & & \\
\hline 1 & (Constant) & .102 & .025 & & 4.035 & .000 \\
\hline
\end{tabular}




\begin{tabular}{|c|c|c|c|c|c|}
\hline CR & -.002 & .002 & -.078 & -.717 & .475 \\
\hline DAR & -.103 & .018 & -.661 & -5.552 & .000 \\
\hline Firm Size & .000 & .001 & .031 & .335 & .739 \\
\hline \begin{tabular}{|l|} 
WCTO \\
\end{tabular} & .000 & .000 & .132 & 1.091 & .278 \\
\hline \multicolumn{6}{|c|}{ a. Dependent Variable: ROA } \\
\hline
\end{tabular}

Berdasarkan hasil uji t yang terdapat pada tabel IV.12, maka pengaruh current ratio, debt to asset ratio, firm size, dan perputaran modal kerja secara parsial berpengaruh terhadap profitabilitas dapat diuraikan sebagai berikut:

1. Variabel current ratio $\left(\mathrm{X}_{1}\right)$ mempunyai nilai thitung-0,717 dengan tingkat signifikan 0,475. Nilai thitung yang diperoleh lebih besar dari nilai $-t_{\text {tabel }}(-$ 1,98525, dimana $\mathrm{df}=\mathrm{n}-\mathrm{k}=95$ ) dan nilai signifikansi tidak lebih kecil dari 0,05 dengan demikian hipotesis ditolak, hasil hipotesis menunjukkan bahwa current ratio tidak berpengaruh terhadap profitabilitas.

2. Variabel debt to asset ratio $\left(\mathrm{X}_{2}\right)$ mempunyai nilai $t_{\text {hitung-5,552 dengan }}$ tingkat signifikan 0,000 . Nilai $t_{\text {hitung }}$ yang diperoleh lebih kecil dari nilai $\mathrm{t}_{\text {tabel }}(-1,98525$, dimana $\mathrm{df}=\mathrm{n}-\mathrm{k}=95)$ dan nilai signifikansi tidak lebih kecil dari 0,05 dengan demikian hipotesis diterima, hasil hipotesis menunjukkan bahwa debt to asset ratioberpengaruh negatif signifikan terhadap profitabilitas.

3. Variabel firm size $\left(\mathrm{X}_{3}\right)$ mempunyai nilai $t_{\text {hitung }} 0,335$ dengan tingkat signifikan 0,739 . Nilai thitung yang diperoleh lebih kecil dari nilai $t_{\text {tabel }}(1,98525$, dimana $\mathrm{df}=\mathrm{n}-\mathrm{k}=95$ ) dan nilai signifikansi tidak lebih kecil dari 0,05 dengan demikian hipotesis ditolak, hasil hipotesis menunjukkan bahwa firm sizetidak berpengaruh terhadap profitabilitas.

4. Variabel perputaran modal kerja $\left(\mathrm{X}_{4}\right)$ mempunyai nilai $t_{\text {hitung }} 1,091$ dengan tingkat signifikan 0,278 . Nilai $t_{\text {hitung }}$ yang diperoleh lebih kecil dari nilai $t_{\text {tabel }}$
$(1,98525$, dimana $\mathrm{df}=\mathrm{n}-\mathrm{k}=95)$ dan nilai signifikansi tidak lebih kecil dari 0,05 dengan demikian hipotesis ditolak, hasil hipotesis menunjukkan bahwa perputaran modal kerja tidak berpengaruh terhadap profitabilitas.

C. Pembahasan hasil penelitian

Berdasarkan hasil pengujian, current ratio secara parsial tidak berpengaruh terhadap profitabilitas pada perusahaan Wholesale dan Retail Trade yang terdaftar di Bursa Efek Indonesia pada periode 2013-2017.

Hasil penelitian ini tidak sesuai dengan teori tersebut akan tetapi sejalan dengan jurnal penelitian, halini mungkin dikarenakan jumlah aset lancar yang dimiliki perusahaan tidak mempengaruhi kinerja perusahaan sehingga tidak mempengaruhi laba yang diperoleh perusahaan.

Berdasarkan hasil pengujian, Debt to Asset Ratio secara parsial berpengaruh terhadap profitabilitas pada perusahaan Wholesale dan Retail Trade yang terdaftar di Bursa Efek Indonesia pada periode 20132017.

Hasil penelitian ini sesuai dengan teori dan jurnal penelitian, hal ini dikarenakan jumlah hutang yang besar akan memunculkan risiko keuangan sehingga mempengaruhi laba yang diperoleh perusahaan.

Berdasarkan hasil pengujian, Firm Size secara parsial tidak berpengaruh terhadap profitabilitas pada perusahaan Wholesale dan Retail Trade yang terdaftar di Bursa Efek Indonesia pada periode 20132017.

Hasil penelitian ini tidak sesuai dengan teori tersebut akan tetapi sejalan 
dengan jurnal penelitian, hal ini mungkin dikarenakan perusahaan tidak menggunakan aset yang tersedia secara optimal sehingga laba yang diperoleh perusahaan tidak meningkat.

Berdasarkan hasil pengujian, perputaran modal kerja secara parsial tidak berpengaruh terhadap profitabilitas pada perusahaan Wholesale dan Retail Trade yang terdaftar di Bursa Efek Indonesia pada periode 2013-2017.

Hasil penelitian ini tidak sesuai dengan teori tersebut akan tetapi sejalan dengan jurnal penelitian, hal ini mungkin dikarenakan jumlah modal kerja yang dimiliki perusahaan tidak mempengaruhi kinerja perusahaan sehingga tidak mempengaruhi laba yang dihasilkan perusahaan.

\section{KESIMPULAN DAN SARAN a. Kesimpulan}

Berdasarkan penelitian yang telah dilakukan, maka peneliti menarik kesimpulan sebagai berikut :

1. Current ratio, Firm size, Perputaran modal kerja tidak berpengaruh secara parsial terhadap Return On AssetpadaperusahaanWholesale dan Retail Trade yang terdaftar di Bursa Efek Indonesia pada periode 20132017

2. Debt to Asset Ratio berpengaruh secara parsial terhadap Return On Asset pada perusahaan Wholesale dan Retail Trade yang terdaftar di Bursa Efek Indonesia pada periode 2013-2017

3. Current Ratio, Debt to Asset Ratio, Firm Size, dan perputaran modal kerja secara simultan berpengaruh signifikan terhadap profitabilitas pada perusahaan Wholesale dan Retail Trade yang terdaftar di Bursa Efek Indonesia pada periode 2013-2017.

\section{b. Saran}

Berdasarkan penelitian yang dilakukan, peneliti akan memberikan beberapa saran terkait hasil dari pengamatan sebagai berikut:

1. Bagi Penulis, disarankan untuk menambah atau mengganti variabel penelitian yang lain.

2. Bagi perusahaan Wholesale dan Retail Trade, disarankan untuk mempertahankan dan meningkatkan kinerja perusahaan agar dapat menjaga kelangsungan hidup perusahaan

3. Bagi investor dan calon investor, disarankan untuk memperhatikan kinerja perusahaan sebelum melakukan investasi, terutama hutang yang dimiliki perusahaan.

4. Bagi Universitas Prima Indonesia, disarankan untuk menambah bahan pustaka bagi mahasiswa.

5. Bagi peneliti selanjutnya, disarankan untuk mengganti jenis perusahaan dan jangka waktu penelitian.

\section{DAFTAR PUSTAKA}

Brigham, Eugene. F dan Joel F. Houston. 2010. Dasar-Dasar Manajemen Keuangan, Buku 1 Ed. 11. Jakarta : Salemba Empat.

Burhanudin. (2017). Pengaruh Struktur Modal, Perputaran Modal Kerja Terhadap Profitabilitas (Perusahaan Otomotif yang Terdaftar di Bursa Efek Indonesia). Jurnal Akuntansi : Vol. 3 No. 2. Januari 2017, pISSN : 2339-2436.

Ghozali, Imam. 2016. Aplikasi Analisis Multivariate dengan Program SPSS. 
Semarang : Badan Penerbit Universitas Diponegoro (BPUD).

Hartono, Jogiyanto. 2016. Teori Portofolio dan Analisis Investasi, Ed. 10. Yogyakarta : BPFE Yogyakarta.

Heri. 2016. Analisis Laporan Keuangan, Integrated and Comprehensive Edition. Jakarta : Grasindo.

Husnan, Suad. 2012. Dasar-Dasar Teori Portofolio \& Analisa Sekuritas, Ed. 4. Yogyakarta : UPP STIM YKPN.

Meidiyustiani, Rinny. (2016). Pengaruh Modal Kerja, Ukuran Perusahaan, Pertumbuhan Penjualan dan Likuiditas Terhadap Profitabilitas Pada Perusahaan Manufaktur Sektor Industri Barang Konsumsi yang Terdaftar di Bursa Efek Indonesia (BEI) Periode Tahun 2010-2014. Jurnal Akuntansi dan Keuangan Vol. 5 No. 2 Oktober 2016, ISSN: 22527141.

Munawir, S. 2016. Akuntansi Laporan Keuangan. Yogyakarta : Liberty Yogyakarta.

Nurdiana, Diah. (2018). Pengaruh Ukuran Perusahaan Dan Likuiditas Terhadap Profitabilitas. JurnalVol. XII. No.6, Juli 2018, ISSN 1693-2617.

Pangestuti, Cholifia Dwi Agustin. (2016). Pengaruh Perputaran Modal Kerja, Ukuran Perusahaan, Operating Leverage, Financial Leverage Terhadap Profitabilitas. Jurnal Ilmu dan Riset Manajemen : Volume 5, Nomor 7, Juli 2016, ISSN : 2461-0593.

Pramesti, Dian et.al. (2016). Pengaruh Rasio Likuiditas, Leverage, Aktivitas, dan Firm Size Terhadap Profitabiltas Perusahaan Sub Sektor Otomotif dan
Komponen di Bursa Efek Indonesia. Seminar Nasional IENACO. ISSN : 23374349.

Riyanto, Bambang. 2010. Dasar Dasar Pembelanjaan Perusahaan. Yogyakarta : BPFE.

Sansasilia, Sefty Setyafani. (2015). Pengaruh Rasio Likuiditas dan Rasio Solvabilitas Terhadap Profitabilitas pada Perusahaan Perbankan. Jurnal Ilmu dan Riset Manajemen Volume 4, Nomor 6, Juni 2015, ISSN : 2461-0593.

Sawir, Agnes. 2010. Analisa Kinerja Keuangan dan Perencanaan Keuangan Perusahaan. Jakarta : PT. Gramedia Pustaka Utama.

Silaban, Pasaman dan Rusliaman Siahaan. 2011. Manajemen Keuangan Teori dan Aplikasi, Ed. 2. Medan : Falkutas Ekonomi Universitas HKBP Nomensen.

Sugiyono. 2016. Metode Penelitian Kuantitatif Kualitatif \& RND. Bandung : Alfabet.

Syamsuddin, Lukman. 2011. Manjemen Keuangan Perusahaan, Edisi baru. Jakarta : Rajawalipers.

Zulganef. 2013. Metode Penelitian Sosial dan Bisnis, Ed. 1 Cetakan kedua. Yogyakarta : Graha Ilmu.

www.idx.co.id (diakses tanggal : 7 Mei 2018) 